Laporan Penelitian

\title{
Pengaruh mometasone furoate terhadap kadar Interleukin 6 serum pada penderita hipertrofi adenoid
}

\author{
Rus Suheryanto, Surya Parlaungan Harahap, Iriana Maharani \\ Departemen Departemen Ilmu Kesehatan Telinga Hidung Tenggorok-Bedah Kepala dan Leher \\ Fakultas Kedokteran Universitas Brawijaya/ Rumah Sakit Dr. Saiful Anwar \\ Malang
}

\begin{abstract}
ABSTRAK
Latar belakang: Inflamasi adenoid ditandai dengan ditemukannya pembesaran ukuran adenoid atau hipertrofi adenoid. Telah banyak dilakukan penelitian yang mendukung IL-6 merupakan dasar patofisiologi terjadinya hipertrofi adenoid sehingga dibutuhkan terapi yang dapat mengurangi peran IL-6. Saat ini, kortikosteroid intranasal menjadi pilihan terapi pada hipertrofi adenoid karena memiliki efek anti inflamasi. Terdapat penelitian mengenai manfaat penggunaan kortikosteroid intranasal terhadap penderita hipertrofi adenoid, dimana terjadi penurunan kadar IL-6, tetapi pengaruhnya terhadap kadar IL-6 serum tidak diteliti. Tujuan: Mengetahui pengaruh pemberian mometasone furoate semprot hidung terhadap kadar IL-6 serum pada penderita hipertrofi adenoid. Metode: One group pre and post test design ini melibatkan 16 subjek. Dilakukan pemeriksaan foto polos skull lateral soft tissue dan pengambilan darah tepi untuk menghitung kadar IL-6 serum. Diberikan terapi mometasone furoate semprot hidung selama 6 minggu. Setelah 2 minggu dan 6 minggu dilakukan pengambilan darah tepi untuk menghitung kadar IL-6 serum, serta evaluasi foto polos skull lateral soft tissue setelah 6 minggu. Hasil: Terdapat perbedaan bermakna antara kadar IL-6 serum sebelum dan sesudah perlakuan baik, pada minggu kedua maupun minggu keenam $(\mathrm{p}=0.00)$. Terdapat perbedaan bermakna antara nilai foto polos skull lateral soft tissue sebelum dan sesudah perlakuan $(\mathrm{p}=0.00)$. Berdasarkan uji Pearson, nilai kadar IL-6 serum darah berkorelasi secara signifikan yang bersifat negatif $(\mathrm{p}<0,05)$ dengan foto polos skull lateral sebelum dan sesudah perlakuan dengan hasil -0,819 dan -0,692. Kesimpulan: Mometasone furoate semprot hidung dapat menurunkan kadar IL-6 serum pada penderita hipertrofi adenoid secara bermakna, disertai dengan mengecilnya ukuran adenoid, penurunan gejala dan keluhan penderita hipertrofi adenoid.
\end{abstract}

Kata kunci: Hipertrofi adenoid, Interleukin 6, Mometasone Furoate

\section{ABSTRACT}

Background: Adenoid inflammation is characterized by adenoid hypertrophy (AH). Numerous studies had stated that Interleukin 6(IL-6) is the pathophysiological basis for the occurrence of AH, thus, a therapy is needed to reduce the role of IL-6. Intranasal corticosteroid (IC) is the drug-of-choice for AH for its anti-inflammatory nature. Previous research had shown a decrease in IL-6 levels in adenoid tissue after IC administration, but its effect on IL-6 serum level had not yet been studied. Purpose: To find out the effect of Mometasone Furoate (MF) on IL-6 serum level in AH patients. Methods: One group pre and post test design, involving 16 subjects, underwent a soft tissue skull lateral plain $x$-ray, also a peripheral blood examination for IL-6 serum level. Afterwards, subjects were treated with MF nasal spray for 6 weeks. The IL-6 serum level was evaluated after 2 and 6 weeks, and the soft tissue $x$-ray was assessed after 6 weeks. Results: There were significant differences between IL-6 serum levels before and after treatment both in the second and sixth week $(p=0.00)$. There were significant differences between the value of soft tissue skull lateral plain $x$-ray before and after treatment $(p=0.00)$. Based on the Pearson test, IL-6 serum levels correlated significantly negatively $(p<0.05)$ with soft tissue skull lateral plain $x$-ray before and after treatment with results -0.819 and -0.692. Conclusion: MF nasal spray significantly reduce IL-6 serum levels in AH patients, reducing adenoid size and decreasing symptoms of AH patients. 
Keywords: Adenoid hypertrophy, Interleukin 6, Mometasone Furoate

Alamat korespondensi: dr. Surya Parlaungan Harahap Sp.T.H.T.K.L(K). Departemen Ilmu Kesehatan Telinga Hidung Tenggorok-Bedah Kepala dan Leher Fakultas Kedokteran Universitas Brawijaya/ RSUD Dr. Saiful Anwar Malang. Email: suryaparlaungan@gmail.com

\section{PENDAHULUAN}

Adenoid merupakan bagian dari serangkaian jaringan limfoid di saluran pernapasan bagian atas yang disebut cincin Waldeyer. Pada anak usia dini adenoid menjadi lokasi awal terjadinya kontak imunologi terhadap antigen inhalasi. ${ }^{1}$ Adenoid berperan dalam sistem pertahanan tubuh, walaupun demikian dapat mengalami pembesaran atau hipertrofi dengan insiden yang cukup tinggi. ${ }^{2,3}$

Penatalaksanaan inflamasi adenoid dapat berupa medikamentosa atau tindakan secara operatif. Adenoidektomi masih menjadi terapi utama pada hipertrofi adenoid meskipun pada beberapa kasus hanya menunjukkan manfaat dalam jangka waktu yang pendek. ${ }^{4}$

Salah satu pilihan penatalaksanaan medikamentosa adalah pemberian kortikosteroid intranasal yang pertama kali berhasil diperkenalkan oleh Demain dan Goetz. Efek anti inflamasi kortikosteroid menjadi dasar pemberian kortikosteroid untuk mengurangi inflamasi pada adenoid melalui mekanisme menekan produksi sitokin, sel mast, basofil, mencegah perubahan sintesis IgE oleh sel B, menurunkan migrasi sel inflamasi, menekan tahapan ekspresi granulocyte macrophage colony stimulating factor (GM-CSF), IL-6, IL-8, regulated on activation normal $t$-cell expresed and secreted (RANTES), kemokin, penurunan jumlah sel epitel cluster of diferentiation 3 (CD3), CD4+, CD8+, CD25+ dan IL-4. ${ }^{5}$

Peningkatan kadar IL-6 jaringan adenoid sebagai akibat dari stimuli antigen yang terus-menerus dapat menyebab disfungsi limfosit sehingga menyebabkan hipertrofi, mengaktifkan sel endotel untuk menghasilkan molekul adhesi, IL-8, dan IL-6 itu sendiri sehingga kadar IL-6 serum meningkat, serta meningkatkan migrasi sel $\mathrm{T}$ dan sel $\mathrm{B}$ ke daerah terjadinya peradangan. Peningkatan IL-6 yang berkepanjangan menyebabkan apoptosis neutrofil dan akumulasi monosit di daerah peradangan di adenoid yang merupakan petanda adanya inflamasi kronis. ${ }^{6}$

Ada penelitian mengenai manfaat penggunaan kortikosteroid intranasal terhadap penderita hipertrofi adenoid, bahwa terdapat penurunan kadar IL-6 pada jaringan adenoid hipertrofi setelah pemberian kortikosteroid intranasal, tetapi pengaruhnya terhadap kadar IL-6 serum tidak diteliti.

Penelitian ini bertujuan untuk mengetahui pengaruh pemberian mometasone furoate semprot hidung terhadap kadar IL-6 serum pada penderita hipertrofi adenoid.

\section{METODE}

Penelitian ini merupakan suatu penelitian the one group pre and post test design. Pengambilan data dilakukan sebelum dan setelah perlakuan tanpa dibandingkan dengan kelompok kontrol. Penelitian menggunakan subjek manusia, yaitu semua penderita hipertrofi adenoid yang memenuhi kriteria sebagai sampel, dan dilakukan pemeriksaan IL-6 serum sebelum dan sesudah diberi mometasone furoate semprot hidung selama 6 minggu.

Pengambilan sampel pada penelitian ini menggunakan consecutive sampling. Kriteria inklusi yaitu anak berusia 5-14 tahun dengan gejala dan tanda hipertrofi adenoid ditunjang dengan pemeriksaan foto polos 
kepala posisi lateral dengan soft tissue setting menggunakan metode Cohen dan Konak dengan $\mathrm{AC} / \mathrm{SfP}<1,1$. Selain itu, hasil tes alergi Skin Prick Test negatif dan tidak sedang mengalami radang akut dengan pemeriksaan lekosit dan C-Reactive Protein (CRP) dalam batas normal, yaitu lekosit : $5.000-11.000 / u l$ dan CRP $<0.8 \mathrm{mg} / \mathrm{dl}$. Kriteria eksklusi yaitu menderita cacat bawaan daerah wajah, rongga mulut, dan hidung dan kelainan obstruksi hidung.

Subjek yang bersedia ikut dalam penelitian dilakukan pengukuran kadar IL-6 serum dengan cara ELISA sebelum dilakukan perlakuan. Subjek diberikan mometasone furoate semprot hidung dengan dosis $100 \mu \mathrm{g}$ per hari untuk pasien usia 5-11 tahun, dan $200 \mu \mathrm{g}$ per hari untuk usia 1214 tahun. Penggunaan mometasone furoate semprot hidung dilakukan selama 6 minggu. Subjek diminta untuk datang kembali pada minggu kedua untuk melakukan pengukuran kadar IL-6 serum dan minggu ke 6 untuk menilai hasil pengobatan dengan melakukan pengukuran kadar IL-6 serum dan evaluasi dengan foto polos skull lateral soft tissue. Semua subjek penelitian menjalani anamnesa dan penilaian gejala klinis OSA sebelum dan sesudah penelitian dengan menggunakan kuesioner OSA-18 terdiri atas 18 pertanyaan yang diisi oleh orang tua atau pengasuh dari subjek penelitian. Survey ini terdiri atas 18 pertanyaan yang tergabung dalam 5 kelompok pertanyaan yaitu gangguan tidur (4 pertanyaan), gangguan fisik (4 pertanyaan), gangguan emosional (4 pertanyaan), masalah sehari-hari (3 pertanyaan) dan masalah pada pengasuh atau orang tua (4 pertanyaan).

Penimbangan botol sediaan mometasone furoate semprot hidung dilakukan pada minggu ke dua, minggu ke empat dan minggu ke enam untuk menilai kepatuhan penderita dalam menggunakan mometasone furoate semprot hidung.

Semua data yang diperoleh diolah menggunakan program Statistical Package for the Social Sciences (SPSS) 23.0.0. Normalitas variabel diuji dengan tes Shapirowilk. Menguji perbedaan kadar IL-6 serum dan foto skull lateral soft tissue pada penderita hipertrofi adenoid sebelum dan setelah pemberian mometasone furoate semprot hidung, dianalisis dengan uji-t berpasangan bila terdistribusi normal dan analisis Wilcoxon bila tidak terdistribusi normal.

\section{HASIL}

Penelitian dilakukan pada bulan Oktober 2018 sampai Januari 2019 dengan jumlah sampel 16 orang yang memenuhi kriteria penelitian. Karakteristik umum subjek penelitian meliputi jenis kelamin, usia, dan kelompok usia tercantum dalam tabel 1.

Tabel 1. Karakteristik umum subjek penelitian

\begin{tabular}{|c|c|c|}
\hline & n & $\%$ \\
\hline \multicolumn{3}{|l|}{ Jenis kelamin } \\
\hline Laki-laki & 9 & 56,3 \\
\hline Perempuan & 7 & 43,8 \\
\hline \multicolumn{3}{|c|}{ Kelompok Usia } \\
\hline 5-11 tahun & 12 & 75 \\
\hline \multirow[t]{2}{*}{ 12-14 tahun } & 4 & 25 \\
\hline & Rerata & \\
\hline Usia & $8,56 \pm 2,92$ & \\
\hline
\end{tabular}


Tabel 2. Karakteristik klinis subjek penelitian

\begin{tabular}{lcc}
\hline Karakteristik Klinis & n & \% \\
\hline Keluhan & & 16 \\
$\quad$ Tidur Mendengkur & 12 & 75 \\
Hidung Buntu & 12 & 62,5 \\
Bangun Gelagepan & 10 & 43,8 \\
Suara Sengau & 7 & 0 \\
Bernafas melalui mulut & 0 & 0 \\
\hline
\end{tabular}

Rerata jumlah nilai kuesioner OSA18 sebelum perlakuan adalah $35,88 \pm 4,69$ dengan nilai tertinggi 46 dan terendah 28 . Setelah diberikan perlakuan selama 6 minggu, rerata jumlah kuesioner OSA-18 adalah 24,50 $\pm 2,28$ dengan nilai tertinggi 27 dan terendah 20. (Gambar 1)

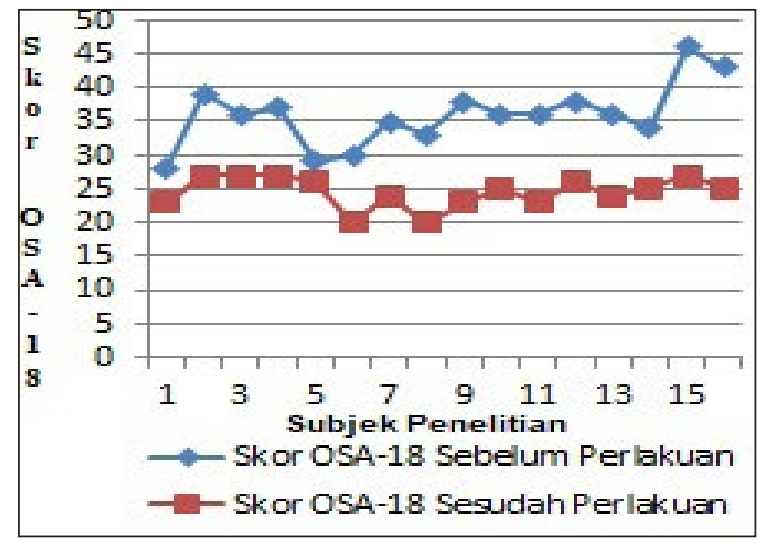

Gambar 1. Grafik nilai skor OSA-18

Rerata hasil pengukuran foto polos skull lateral sebelum pemberian semprot hidung adalah $0,634 \pm 0,14$ dengan nilai tertinggi 0,8 dan terendah 0,32 . Rerata hasil pengukuran foto polos skull lateral sesudah pemberian semprot hidung adalah $0,97 \pm 0,14$ dengan nilai tertinggi 1,2 dan terendah 0,75 . Semakin rendah nilai pada hasil pengukuran foto polos skull lateral menunjukkan bahwa semakin besar ukuran adenoid pada subjek penelitian. Adenoid dikatakan membesar apabila AC/SfP kurang dari 1,1. Pada penelitian ini, perubahan ukuran terlihat pada saat pengukuran Air of Column setelah diberikan semprot hidung, sedangkan ukuran pada Soft Palate (SfP) tetap. Pada penelitian ini, terdapat 3 subjek penelitian memiliki nilai perbandingan $\mathrm{AC} /$ Sfp lebih dari 1,1 setelah diberikan semprot hidung selama 6 minggu sehingga kesimpulan pada foto polos menunjukkan adenoid dalam batas normal.

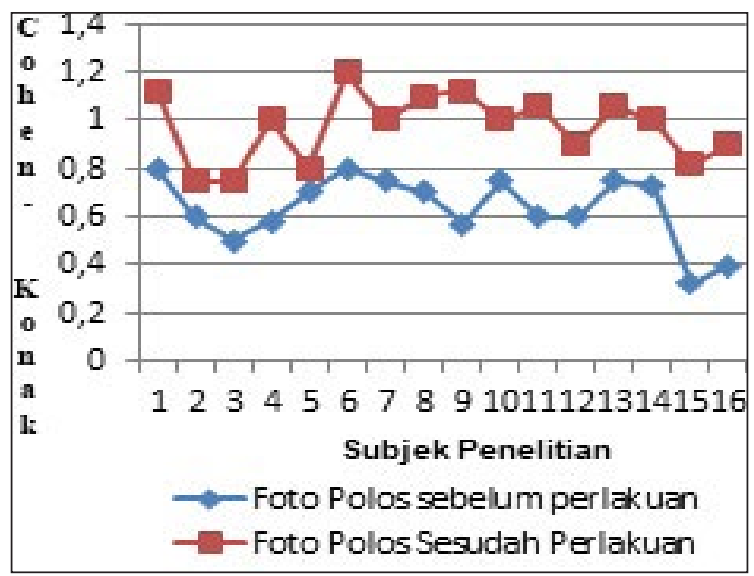

Gambar 2. Grafik hasil pengukuran perbandingan Air Column dan Soft Palate Pada foto polos Skull Lateral Soft Tissue

Berdasarkan uji Pearson, nilai foto polos skull lateral berkorelasi secara signifikan yang bersifat negatif $(\mathrm{p}<0,05)$ dengan jumlah skor OSA-18. Pada koefisien korelasi antara jumlah skor OSA-18 dan foto polos skull lateral sebelum -0,854 dan sesudah perlakuan $-0,844$. Hal ini menunjukkan bahwa semakin tinggi nilai pada pembacaan hasil foto polos skull lateral, jumlah skor OSA-18 juga akan semakin rendah.

Hasil analisa IL-6 didapatkan hasil semua subjek penelitian mengalami penurunan kadar IL-6 serum darah. Hasil pemeriksaan IL-6 serum darah dapat dilihat pada Gambar 3. 


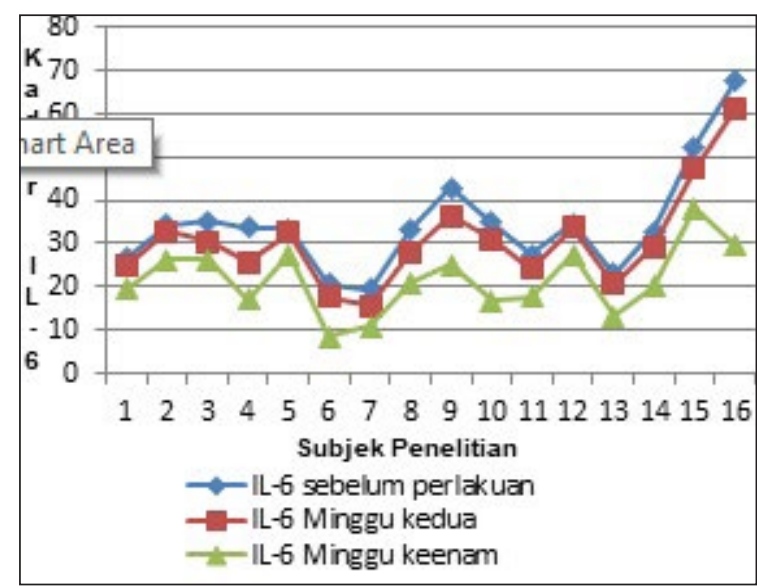

Gambar 3. Grafik hasil pemeriksaan IL-6 serum darah

Berdasarkan uji Pearson, nilai kadar IL-6 serum darah berkorelasi secara signifikan yang bersifat negatif $(\mathrm{p}<0,05)$ dengan foto polos skull lateral. Pada koefisien korelasi antara kadar IL-6 serum darah dan foto polos skull lateral sebelum -0,819 dan sesudah perlakuan -0,692. Hal ini menunjukkan bahwa semakin rendah nilai kadar IL-6 serum darah maka nilai pada pembacaan hasil foto polos skull lateral semakin tinggi. Semakin tinggi nilai pada pembacaan foto polos skull lateral menunjukkan bahwa semakin kecil ukuran adenoid.

\section{DISKUSI}

Proporsi jenis kelamin subjek pada penelitian ini adalah perempuan sebesar $56,3 \%$ dan laki-laki sebesar 43,8\%. Gowda, ${ }^{7}$ melaporkan proporsi jenis kelamin pada penderita hipertrofi adenoid adalah 33 laki-laki (55\%) dan 27 perempuan (45\%). ${ }^{7}$ Perbandingan antara perempuan dan laki-laki tidak berbeda signifikan. Hal ini dipengaruhi oleh ukuran saluran napas antara perempuan dan laki-laki sama pada masa anak-anak. Saluran napas pada laki-laki akan memiliki ukuran yang lebih besar dibandingkan perempuan setelah masa pubertas, namun terdapat lebih banyak jaringan lunak sehingga mudah kolaps, dan prevalensi terjadinya OSA lebih tinggi pada laki-laki daripada perempuan. $^{8}$

Rerata usia subjek penelitian adalah 8,56 tahun dengan kelompok umur 5-11 tahun sebanyak 12 orang $(75 \%)$ dan 12 14 tahun sebanyak 4 orang (25\%). Secara fisiologis, pembesaran pada adenoid dimulai dari usia 3 tahun hingga 7 tahun karena pada rentang usia tersebut adenoid sangat aktif dalam sistem imunitas tubuh. Ukuran adenoid mencapai masa puncaknya pada usia 6-7 tahun dan merupakan saat terbesar aktivitas imunitasnya. Adenoid kemudian akan mengalami regresi mulai usia 8 tahun hingga akhir masa pubertas. ${ }^{9}$

Adenoid berperan sebagai lini pertama pertahanan pada saluran napas yang akan kontak dengan antigen dan mendorong perkembangan imunitas humoral dan seluler. Manusia mulai kehilangan imunitas pasif dari ibu saat berumur 6 bulan dan adenoid berperan penting dalam imunitas tubuh manusia terutama pada tahun pertama kehidupan yang kemudian akan membentuk respon kekebalan tubuh sendiri. ${ }^{9}$

Dari hasil anamnesa terhadap subjek penelitian dan orang tua didapatkan semua subjek penelitian mengalami keluhan mendengkur saat tidur (100\%), diikuti keluhan hidung buntu $(75 \%)$, terbangun malam hari karena gelagepan (63\%), dan suara sengau (44\%). Hal ini sesuai dengan gejala utama pada penderita hipertrofi adenoid yaitu tidur mendengkur dan hidung buntu.

Pada anak-anak dengan hipertrofi adenoid terjadi gangguan pernapasan pada daerah hidung sehingga menyebabkan keluhan mendengkur, hidung buntu, bernapas melalui mulut dan terkadang terjadi henti napas diwaktu tidur. Saat ini masalah gangguan tidur pada anak-anak lebih mendapat perhatian, dan gangguan tidur pada anak-anak dikaitkan dengan adanya gangguan patensi pada saluran napas atas terutama adanya masalah hipertrofi adenoid pada populasi anak-anak. Gangguan tidur dapat menimbulkan terjadinya hipoksia pada anak-anak dan apabila berkepanjangan akan memicu terjadinya perubahan perilaku, 
gangguan konsentrasi, perilaku agresif, dan gangguan belajar. ${ }^{9}$

Hasil rata-rata jumlah nilai skor OSA18 mengalami penurunan secara bermakna setelah subjek mendapatkan perlakuan selama 6 minggu. OSA-18 dapat digunakan sebagai alat ukur untuk menilai kualitas hidup penderita hipertrofi adenoid setelah pemberian steroid intranasal. OSA- 18 terdiri atas 18 pertanyaan yang mudah digunakan dan memiliki korelasi yang baik dengan indeks gangguan respirasi. ${ }^{10}$

Nilai foto polos skull lateral berkorelasi secara signifikan yang bersifat negatif dengan jumlah skor OSA-18. Hal ini menunjukkan bahwa semakin tinggi nilai pada pembacaan hasil foto polos skull lateral, jumlah skor OSA-18 juga akan semakin rendah.

Penggunaan mometasone furoate semprot hidung dapat mengurangi gejala dan ukuran adenoid pada penderita hipertrofi adenoid. Mekanisme steroid intranasal untuk mengurangi gejala masih belum pasti. Beberapa penelitian menunjukkan adanya hubungan antara ukuran adenoid dengan gejala pada hipertrofi adenoid. Penurunan gejala kemungkinan disebabkan oleh berkurangnya ukuran adenoid setelah penggunaan steroid semprot hidung. ${ }^{11}$

Inflamasi kronis pada adenoid dapat mengakibatkan adenoid mengalami hiperplasia dan hipertrofi oleh karena multiplikasi sel-sel limfoid yang sampai batas tertentu tidak mampu lagi membelah diri sehingga sel-sel tersebut mengalami hipertrofi (pembesaran ukuran sel). Pemberian mometasone furoate semprot hidung selama 4 minggu dapat mengurangi inflamasi pada permukaan adenoid yang disertai dengan mengecilnya ukuran adenoid. ${ }^{10}$ Beberapa mekanisme seperti aksi limfolitik secara langsung, inhibisi terhadap proses inflamasi dan perubahan terhadap flora bakteri adenoid dapat menjadi teori untuk menjelaskan mekanisme steroid menurunkan volume jaringan adenoid dan menurunkan keluhan gejala pada hipertrofi adenoid. ${ }^{12}$
Pada penelitian ini, pasien dengan hasil foto skull lateral yang lebih rendah memiliki persentase pengecilan ukuran adenoid yang lebih besar. Pada penelitian oleh Goldbart, ${ }^{13}$ menunjukkan bahwa jaringan adenoid pada pasien yang mengalami hipertrofi adenoid memiliki glucocorticoid receptor (GR) yang lebih banyak. Pada penderita hipertrofi adenoid dan disertai dengan OSAS, proses inflamasi pada daerah retropalatal dan nasofaring akan lebih tinggi dengan ditandai adanya keluhan mendengkur akibat sumbatan pada jalan nafas. Peningkatan mediator inflamasi yang dilepas seperti sitokin pada penderita hipertrofi adenoid berperan terhadap regulasi ekspresi gen GCR- $\alpha$. Ekspresi gen GCR- $\alpha$ akan meningkat seiring dengan tingginya tingkat keparahan penyakit. Hal ini akan menyebabkan pasien yang mengalami hipertrofi adenoid yang lebih berat akan memiliki respon yang lebih baik terhadap pengobatan dengan kortikosteroid semprot hidung.

Hasil penelitian ini menunjukan adanya penurunan kadar IL-6 serum darah setelah subjek penelitian mendapatkan terapi mometasone furoate semprot hidung. Kadar IL-6 serum mulai menunjukkan penurunan setelah diberikan mometasone furoate semprot hidung selama 2 minggu dan semakin menurun setelah 6 minggu. Penderita hipertrofi adenoid yang mendapatkan terapi kortikosteroid intranasal memiliki kadar IL-6 lebih rendah daripada yang tidak diberikan terapi kortikosteroid intranasal. Efek pemberian kortikosteroid intranasal dapat menurunkan IL-6 setelah 2 minggu menjalani terapi. Kadar IL-6 yang lebih tinggi pada penderita hipertrofi adenoid menjadi petanda suatu proses kronis.

Pada penelitian ini dilakukan uji korelasi untuk mengetahui hubungan antara kadar IL-6 serum dengan foto polos skull lateral sebelum dan sesudah perlakuan. Pada penelitian ini, kadar IL-6 serum berkorelasi secara signifikan yang bersifat negatif $(\mathrm{p}<0,05)$ dengan nilai foto polos skull lateral. 
Hal ini menunjukkan bahwa semakin rendah kadar IL-6 serum, nilai pada pembacaan hasil foto polos skull lateral akan meningkat, yang berarti terjadi pengecilan ukuran adenoid.

Mekanisme trauma mekanik pada proses mendengkur juga dapat mengakibatkan peradangan kronis. Pasien yang mengalami hipertrofi adenoid dengan derajat yang lebih tinggi terutama derajat 3 dan 4 didapatkan kadar IL-6 yang lebih tinggi dibandingkan dengan penderita hipertrofi adenoid dengan derajat yang lebih rendah. Hal ini disebabkan oleh gejala obstruksi yang lebih berat pada penderita dengan derajat yang lebih besar, sehingga produksi IL-6 mRNA lebih tinggi di jaringan untuk mempertahankan fungsi imunologisnya. ${ }^{14}$

Kortikosteroid intranasal dapat menghambat IL-6 yang dilepaskan oleh sel mononuklear adenoid. IL-6 disekresikan oleh sel $\mathrm{T}$ dan fagosit yang memicu proliferasi dan diferensiasi sel $\mathrm{T}$ dan sel B serta meningkatkan acute-phase reactans seperti protein CRP. Kadar IL-6 dapat meningkat pada penderita dengan gangguan bernapas saat tidur, dan peningkatan IL-6 diikuti dengan peningkatan tingkat keparahan penyakit yang dialami oleh penderita hipertrofi adenoid. Pemberian kortikosteroid intranasal dapat menurunkan kadar IL-6 pada limfosit adenoid sehingga terjadi penurunan proliferasi dan diferensiasi sel adenoid dan berkurangnya ukuran adenoid. Penurunan IL-6 pada jaringan adenoid akan disertai pula dengan menurunnya kadar IL-6 serum. Penggunaan kortikosteroid intranasal dapat menjadi terapi yang efektif untuk hipertrofi adenoid karena efeknya yang dapat menurunkan kadar IL-6. ${ }^{15}$

Mometasone furoate merupakan kortikosteroid semprot hidung generasi terbaru yang bersifat lipofilik dan memiliki afinitas terhadap GR lebih tinggi dibanding kortikosteroid lainnya, sehingga lebih mudah menembus membran sel, lebih cepat diabsorpsi oleh mukosa hidung, lebih lama berikatan dengan GR, dan lebih lama berada dalam jaringan hidung. ${ }^{16,17}$ Mometasone furoate memiliki struktur kimia khusus pada rantai 21-dichloro-17 (2-furoate) yang dapat meningkatkan aktivitas inflamasinya, ikatan furoate pada posisi 17 akan meningkatkan afinitas GR, ikatan klorida pada posisi 21 menyebabkan mometasone furoate resisten terhadap degradasi esterase, sedangkan ikatan halogen pada posisi 6 dan 9 meningkatkan potensinya. ${ }^{18}$

Hasil penelitian kami mendapatkan Mometasone furoate semprot hidung dapat menurunkan kadar IL-6 serum pada penderita hipertrofi adenoid secara bermakna, disertai dengan mengecilnya ukuran adenoid, penurunan gejala dan keluhan penderita hipertrofi adenoid.

\section{DAFTAR PUSTAKA}

1. Jeyakumar A, Miller S, Mitchell RB. Adenotonsillar Disease in Children. In: Johnson JT, Rosen CA, editors. In: Bailey's Head and Neck Surgery- Otolaryngology. 5th ed. Philadelphia: Lippincott Williams \& Wilkins; 2014. p. 1430-44.

2. Brodsky L, Poje C. Tonsillitis, Tonsillectomy, and Adenoidectomy. In: Bailey, J BJohnson, T J, Newlands, D S, editors. Head and Neck Surgery- Otolaryngology, 4th Edition 4ed; 2006. p. 1184-94.

3. Aman MA, Djamin R, Punagi AQ. Rasio Adenoid-Nasofaring dan Gangguan Telinga Tengah Pada Penderita Hipertrofi Adenoid. Indonesia Med Association. 2013; 63(1):21-6.

4. Shoby TS. Role of Intranasal Steroid in the Prevention of Reccurent Nasal Symptoms after Adenoidectomy. International Journal of Otolaryngology. 2013: 1-5.

5. Mygind N, Nielsen LP, Hoffmann HJ, Shukla A, Blumberga G, Dahl R. Mode of action intranasal corticosteroids. J Allergy Clin Immunol. 2011;108 (1 Suppl): S1625.

6. Wu Y, Shikh M, Sayed R, Best A, Szakal A, Tew J. IL-6 Produced by Immune ComplexActivated Follicular Dendritic Cells Promotes Germinal Center Reactions, IgG Responses and Somatic Hypermutation. International Immunology. 2009;21(6): $745-56$. 
7. Gowda BV, Smitha SG, Mathew AS. Efficacy of Intranasal Steroid Spray in the Treatment of Post Adenoidectomy Recurrence. Journal of Medical Science and Clinical Research. 2015; 3(1): 3990-96.

8. Fregosi RF, Quan SF, Kaeming KL et al. Sleep-disordered breathing, pharyngeal size and soft tissue anatomy in children. $J$. Appl. Physiol. 2010; 95: 2010-38.

9. Lapinska I, Zawadzka-Glos L. Adenoid And Tonsils Hypertrophy- Symptoms And Treatment. New Med Journal. 2016; 20(4): 103-6.

10. Jung YG, Kim HY, Min, JY, Dhong HJ, Chung SK. Role of Intranasal Topical Steroidin Pediatric Sleep Disordered Breathing and Influence Of Allergy, Sinusitis, and Obesity on Treatment Outcome. Clin. Exp.Otorhinolaryngol. 2011; 4: 27-32.

11. Mohebbi S, Rahmati MB, Omidian P. Assesment of Intranasal Steroid Effect in Management of Adenoid Hypertrophy in Children between 2-11 Years Old. Journal of Pharmacy and Pharmacology. 2014; 211-17.

12. Prassanan P, Islah SAM. Role of Moemetasone Furoate Nasal Spray in Adenoid Hypertrophy in Children With OSA. J Evolution Med. Dent. Sci. 2016; 5: 6891-96.

13. Goldbart AD, Veling MC, Goldman JL. Glucocorticoid Receptor Subunit Expression in Adenotonsillar Tissue of Children with Obstructive Sleep Apnea. International Pediatric Research Foundation, Inc. 2005;57(2):232-36.

14. Yuko EA. Interleukin 6 Levels in Adenotonsillar Hyperplasia and Chronic Recurrent Tonsilitis. Disertasi. Otorhinolaryngology, Head and Neck Surgery. Department of Surgery University of Nairobi. 2012:33-6.

15. Esteitic R, Emani J, Sharma S, Suskind D, Baroody F. Effect of Fluticasone Furoate on Interleukin 6 Secretion from Adenoid Tissue in Children with Obstructive Sleep Apnea. Arch Otolaryngol Head Neck Surg. 2011; 137(6):576-82.

16. Pornsuriyasak P, Assanasen P. Intranasal Cotricosteroid. Siriraj Med J. 2008; 60:905.
17. Berlucchi M, Pedruzzi B. Intranasal Mometasone Furoate For Treatment of Allergic Rhinitis. Clinical Medicine Insights Therapeutics. 2010; 2:761- 9.

18. Derendorf H, Meltzer EO. Molecular and Clinical Pharmacology of Intranasal Corticosteroids Clinical and Therapeutic Implications. Allergy. 2008; 63:1292-300. 